\title{
ERRATUM
}

\section{An efficient route scheduling mechanism for WiMAX network - ERRATUM}

MING-HUANG GUO, DER-JIUNN DENG, HORNG-TWU LIAW and JONG HYUK PARK

doi:10.1017/S0269888914000162 Published by Cambridge University Press 3 October 2014

In the article by Guo et al., 2014, the affiliation for J. Hyuk Park was incorrect. The correct affiliation is given below:

${ }^{3}$ Department of Computer Science and Engineering, Seoul National University of Science and Technology (SeoulTech), 172 Gongreung 2-dong, Nowon-gu, Seoul, 139-743, Korea.

\section{Reference}

Guo, M.-H., Deng, D.-J., Liaw, H.-T. \& Hyuk Park, J. 2014. An efficient route scheduling mechanism for WiMAX network. Knowledge Engineering Review 29, 452-462. 